\title{
Crosstalk between Oxidative Stress and Tauopathy
}

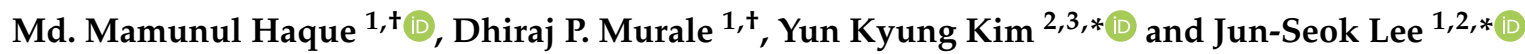 \\ 1 Molecular Recognition Research Center, Korea Institute of Science and Technology (KIST), Seoul 02792, \\ Korea; mamun@chembiol.re.kr (M.M.H.); dhiraj.murale@chembiol.re.kr (D.P.M.) \\ 2 Bio-Med Division, KIST-School UST, Seoul 02792, Korea \\ 3 Convergence Research Center for Diagnosis, Treatment and Care System of Dementia, Brain Science \\ Institute (BSI), Korea Institute of Science and Technology (KIST), Seoul 02792, Korea \\ * Correspondence: yunkyungkim@kist.re.kr (Y.K.K.); junseoklee@kist.re.kr (J.-S.L.) \\ + These authors contributed equally to this work.
}

Received: 2 April 2019; Accepted: 19 April 2019; Published: 22 April 2019

\begin{abstract}
Tauopathy is a collective term for neurodegenerative diseases associated with pathological modifications of tau protein. Tau modifications are mediated by many factors. Recently, reactive oxygen species (ROS) have attracted attention due to their upstream and downstream effects on tauopathy. In physiological conditions, healthy cells generate a moderate level of ROS for self-defense against foreign invaders. Imbalances between ROS and the anti-oxidation pathway cause an accumulation of excessive ROS. There is clear evidence that ROS directly promotes tau modifications in tauopathy. ROS is also highly upregulated in the patients' brain of tauopathies, and anti-oxidants are currently prescribed as potential therapeutic agents for tauopathy. Thus, there is a clear connection between oxidative stress (OS) and tauopathies that needs to be studied in more detail. In this review, we will describe the chemical nature of ROS and their roles in tauopathy.
\end{abstract}

Keywords: oxidative stress; reactive oxygen species; tauopathy

\section{Tau Protein and its Pathogenicity}

Tau protein is expressed abundantly in neurons as well as sparsely in non-neuronal cells like astrocytes and oligodendrocytes [1]. It is a microtubule-binding protein that gives microtubules' integrity, which is critical for neuronal outgrowth [2-4]. It helps microtubules to anchor with other cytoskeletal filaments and organelles for structural support $[5,6]$. Microtubules are continuously assembled and disassembled in cells in a dynamic fashion, and this is maintained by the interaction between tau and the microtubule, which is tightly controlled by several factors. Modification of tau affects microtubule stabilization and other processes related to this protein [7]. Tau modification is promoted by post-translational modifications, conformational changes and the misfolding structure of tau. These modifications lead to the abnormal aggregation of tau into neurofibrillary tangle (NFT) structures. These NFTs accumulate in neurons, causing neuronal degeneration. Therefore, the formation of NFTs represents the significant pathological signatures in many neurodegenerative diseases classified as tauopathies [8]. The level of NFTs and tau modifications are correlated to the severity of the tauopathies, including Alzheimer's disease (AD), Parkinson's disease (PD), frontotemporal dementia (FTD), FTD with parkinsonism linked to chromosome-17 (FTDP-17), frontotemporal lobar degeneration (FTLD), Pick's disease (PiD), progressive supranuclear palsy (PSP), corticobasal neurodegeneration (CBD), dementia pugilistica, etc. [9-12].

\section{Causes of Tauopathies}

Consequently, researchers have been studying the mechanism of tau pathogenesis. Tau is naturally a highly soluble protein, and it undergoes several modifications to become an 
aggregate [13,14]. The mechanisms for NFT formation from tau are still in debate today. Among them, aberrant posttranslational modifications (PTM) are the leading cause of this failure. In this regard, hyperphosphorylation, oxidation, proteolytic cleavage (truncation), acetylation, glycation, nitration, and conformational changes have been suggested to cause the neuro-pathogenicity of tau [13,15-18]. Apart from these hypotheses, imbalances in oxido-redox homeostasis, which produce reactive oxygen species (ROS), play significant roles in tauopathies.

\section{Oxidative Stress and Its Relation to Tauopathies}

ROS are oxygen-containing reactive molecules that are generated by oxidative stress (OS). A moderate level of ROS is critical in cellular defense mechanisms to fight against foreign subjects, and it triggers mitogen-activated protein kinase (MAPK) pathways to modulate cellular signaling (cell cycle, gene expression, cell survival and apoptosis) $[19,20]$. In normal physiological conditions, cells produce small amounts of ROS, and the levels of ROS are balanced by several antioxidant systems [21]. The imbalance between ROS generation and antioxidant defense causes the excessive accumulation of ROS, giving OS to the cells [21,22]. Thus, OS poses a significant threat to the brain, one of the most metabolically active organs, which is vulnerable to OS due to its high oxygen demand [23], abundance of the redox-active metals (iron or copper) [23], polyunsaturated fatty acids (substrates for lipid peroxidation) [24], and deficiency of the glutathione (GSH, an antioxidant to eliminate ROS) levels [25].

In age-related neurodegenerative diseases, balances between OS and antioxidant enzymes are distorted, resulting in various brain damages and neuronal death. There is increasing evidence that OS is one of the leading pathophysiological markers of tauopathies, and all of these findings suggests that there is a clear relationship between OS and the pathophysiology of tauopathies (Figure 1). Moreover, a series of studies have been focused on the elucidation of the mechanisms underlying ROS linked to tauopathies. However, it has not yet been fully understood whether OS is an early causal factor or a result of the cell injuries induced by tau modifications. Therefore, OS creates a scope for the development of therapeutic strategies for tauopathies. Here, we will discuss the cellular origin, reaction mechanism, and relation of ROS in tauopathies.

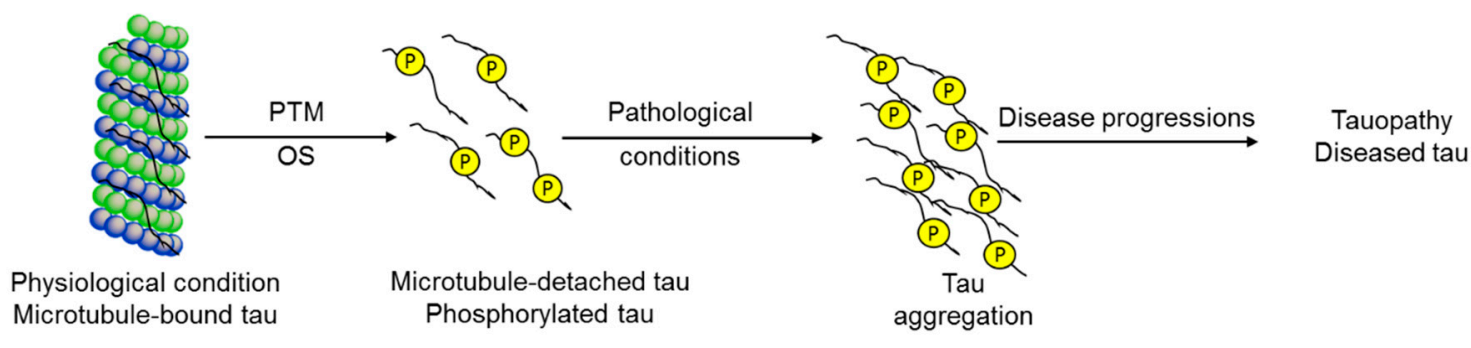

Figure 1. Oxidative stress-mediated tauopathy.

There is clear evidence that OS contributes to neurological deterioration, as well as the oxidative destruction of nucleic acids, proteins, or lipids in the central nervous system (CNS) in tauopathies. OS mediated ROS production is involved in protein oxidation (glycoxidation) or lipid oxidation (lipoxidation) and forms stable advanced end products. These protein products are evident in NFTs in $\mathrm{AD}$, whereas lipid products are present in neurofibrillary pathologies [26]. OS damages nucleic acid (DNA or RNA), and the guanine base is the most susceptible base for oxidative modifications (8-hydroxy-2'-deoxyguanosine, 8-OHdG or 8-hydroxy-2'-guanosine, 8-OHG). These damages by OS are another phenomenon that is associated with tauopathies [27].

$\mathrm{AD}$ is the best-known tauopathy, among others, with increasing prevalence. Accumulation of OS is directly linked to aging, and intimately related to $\mathrm{AD}$ [28]. In fact, OS is one of the first observable markers in $\mathrm{AD}$ progression, even before the appearance of amyloid beta $(\mathrm{A} \beta)$ accumulation [29]. Tau overexpressed cells show increased vulnerability to OS [30,31]. Furthermore, mice (P301S and 
P301L) with AD showed mitochondrial dysfunction, which is associated with increased ROS [32,33]. Several studies indicate that $A \beta$ induces OS, where $A \beta$ serves as a source of ROS to initiate lipid peroxidation [34]. Inversely, $A \beta$ level is increased upon the stimulus of OS but diminishes with time [35]. These phenomena indicate that not only ROS modulates $A \beta$ production, but also $A \beta$ generates excessive ROS in cases of AD. Another report states that free radicals affected the nature and function of neural cells, both in AD and PD [28]. PD is another well-known tauopathy of which OS is the leading contributor. OS is believed to be the main etiology that leads to idiopathic and genetic causes of PD [28]. Alterations in the antioxidant molecules were evident in the early stages of PD [36].

\section{Oxidative Stress and Reactive Oxygen Species}

ROS are generated upon the reduction of $\mathrm{O}_{2}$, and they consist of free radicals and non-radical species. In particular, ROS that play critical roles in the biological system include superoxide anion radical $\left(\mathrm{O}_{2}{ }^{-}\right.$or $\left.\mathrm{O}_{2} \bullet^{-}\right)$, hydroperoxyl radical $\left(\mathrm{HO}_{2}\right)$, hydrogen peroxide $\left(\mathrm{H}_{2} \mathrm{O}_{2}\right)$, hydroxyl radical $(\bullet \mathrm{OH})$, ozone $\left(\mathrm{O}_{3}\right)$, and singlet oxygen $\left({ }^{1} \mathrm{O}_{2}\right)$. Further, ROS also includes peroxyl (ROO•), alkoxyl $(\mathrm{RO} \bullet)$, semiquinone $(\mathrm{SQ} \bullet-)$, and carbonate $\left(\mathrm{CO}_{3} \bullet-\right)$ radicals, along with hypochlorous $(\mathrm{HOCl})$, hypobromous ( $\mathrm{HOBr}$ ), and hypoiodous acids (HOI). Some of the reactive nitrogen species (RNS), which contain an oxygen atom, are also considered as one of these kinds, like the nitric oxide radical $(\mathrm{NO}$ or $\mathrm{NO} \bullet)$, nitrogen dioxide radical $\left(\mathrm{NO}_{2} \bullet\right)$, nitrite $\left(\mathrm{NO}_{2}-\right)$, and peroxynitrite (ONOO-) $[37,38]$.

\section{Major Sources of Oxidative Stress (OS)}

The endogenous sources of OS are: (i) Hypoxia, NO and ONOO, which endorse the generation of ROS in mitochondrial electron transport chain (ETC) [37,39,40]; (ii) an increased level of misfolded proteins [41]; and (iii) intracellular enzymes that produce ROS as metabolic products of their enzymatic processes. These enzymes include NADPH oxidases, flavoenzyme ERO1, cytochrome p450, lipoxygenases, xanthine oxidase, nitric oxide synthases, etc. [37,38,40] Lastly, (iv) free metal cations (such as copper and iron ions) can convert superoxide or hydrogen peroxide into hydroxyl radicals through the Fenton reaction or the Haber-Weiss reaction [42]. A high level of intracellular $\mathrm{Ca}^{2+}$ is also one of the endogenous sources of OS [43,44]. The exogenous sources are ultraviolet light $\left({ }^{1} \mathrm{O}_{2}\right.$ generation), $\gamma$-irradiation $(\bullet \mathrm{OH}$ generation) [45], chemical pollutants, including quinones, nitroaromatics, etc. These sources generate superoxides. It is also reported that smoke and air pollutants also contain ROS which potentially uptake into the body during the respiration process and induce OS $[37,46]$.

\section{Reactive Oxygen Species (ROS) Production in the Body}

\subsection{Mitochondria}

Mitochondria are the major sub-cellular organelles for ROS production. ROS are produced as a byproduct of the electron transport chain reaction for adenosine triphosphate (ATP) generation. Loss of some mitochondrial proteins (cytochrome oxidase, COX; pyruvate dehydrogenase complex, PDHC; and $\alpha$-ketoglutarate dehydrogenase complex, KGDHC) elevate the formation of ROS [47]. OS induces mitochondrial dysfunction by accumulating excessive ROS [30,48]. Increased oxidative damage may lead to mitochondrial DNA mutations, which has been reported to inhibit ATP production in $\mathrm{AD}$ patients [30]. In addition to mitochondria, endoplasmic reticulum, peroxisomes, and microglial cells are also potential sources of ROS.

\subsection{Endoplasmic Reticulum}

The endoplasmic reticulum (ER) is mainly responsible for protein folding and lipid biosynthesis. In the ER, ROS generation is induced by misfolded protein processing, depletion of the GSH, or through the breakage and formation of disulfide bonds [49]. 


\subsection{Peroxisomes}

Peroxisomes participate in many metabolic pathways that include fatty acid oxidation, amino acid catabolism, and phospholipid biosynthesis. They generate the majority of the $\mathrm{H}_{2} \mathrm{O}_{2}$ inside the body, which is balanced by catalases. This $\mathrm{H}_{2} \mathrm{O}_{2}$ level is increased when catalase is not working, or when peroxisomes are damaged. Peroxisomes have been shown to be depleted or damaged by tau aggregation in the rat primary hippocampal neurons, and N2a cells induce OS [31].

\subsection{Microglia}

Microglial cells express a high level of the glutathione peroxidase (GPx) antioxidant enzyme. They also produce ROS, either to eliminate pathogens or during neuroinflammatory processes. Recently, microglial cells were reported as ROS producers in tauopathies [11].

\section{Chemical Properties of ROS}

To gain a clearer perception of the ROS associated biological impact, one needs to understand the chemical properties of ROS.

\subsection{Electronic Configuration of ROS}

Molecular oxygen is paramagnetic species, having two electrons with a parallel spin in the $\pi^{*}$ orbital (Figure 2). Due to this kind of parallel spin, restriction is applied to an oxygen atom to take part in redox reactions. This kind of electronic configuration enables the oxygen atom to accept electrons during the redox reactions, making it unable to oxidize the biomolecules [38]. The molecular oxygen can be converted quite easily into ROS by either energy transfer or electron transfer. Among the ROS, energy transfer from oxygen results in the generation of singlet oxygen. As a result, singlet oxygen has paired electrons with opposite spin, which enhance the oxidizing ability when compared with molecular oxygen. By a one-electron reduction, $\mathrm{O}_{2}$ is converted into superoxide. Further, superoxide, with another one-electron reduction, converts into hydrogen peroxide which later converts into the hydroxyl radical by a one-electron reduction and finally the hydroxyl radical, upon reduction, converts into water. Hence, molecular oxygen can generate ROS by electron or energy transfer, making them more reactive than itself [50-52].

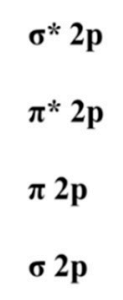

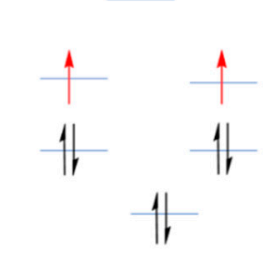

Ground state oxygen

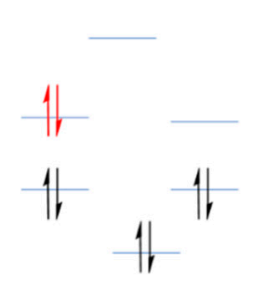

$$
\begin{gathered}
{ }^{1} \mathbf{O}_{2}{ }^{*} \\
\text { Singlet oxygen }
\end{gathered}
$$

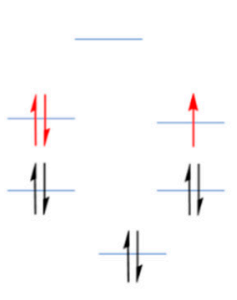

$$
\begin{aligned}
& \mathbf{O}_{2}^{--} \\
& \text {Superoxide } \\
& \text { radical anion }
\end{aligned}
$$

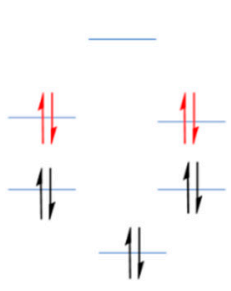

$\mathrm{H}_{2} \mathrm{O}_{2}$ Hydrogen Peroxide

Figure 2. Electronic configuration of reactive oxygen species (ROS).

\subsection{Reactivity Trends of ROS}

To gain more in-depth knowledge into the reactivity of ROS, one should understand the thermodynamics of free radicals. To compare the trend of reactivity of the ROS, the role of reduction potential is vital. To plot the reactivity trend of ROS, one should consider the reduction potential of the one-electron reduction of molecular oxygen $[38,50]$. A few of the main features about the role of reduction potential and reactivity are listed as follows: (a) Reduction potential is the ability of an atom or molecule to acquire the electron; (b) oxidation is the loss of electron, whereas reduction is the gain of electron; and (c) from the above points, it is evident that atoms or molecules with high reduction 
potential have high reactivity as will be easy to reduce. Based on the above assumption, one can easily understand why molecular oxygen is a weak oxidant when compared with another ROS (Figure 3). Here, $\mathrm{O}_{2}$, with the reduction potential of $-0.33 \mathrm{~V}$, is a poor electron acceptor [53]. The superoxide radical also has limited reactivity when compared with its anionic charge, which makes it an electron-rich center [44]. Hydrogen peroxide is generated by the one-electron reduction of superoxide, which is also stable under physiological conditions, even though it has a $+0.38 \mathrm{~V}$ reduction potential [52]. Among the ROS, the hydroxyl radical is the utmost powerful oxidizing agent, with a one-electron reduction potential of $+2.33 \mathrm{~V}$. According to the reduction potential, the ROS reactivity trend can be written as $\bullet \mathrm{OH}>\mathrm{O}_{2} \bullet^{-}>\mathrm{H}_{2} \mathrm{O}_{2}>\mathrm{O}_{2}[50,52]$.

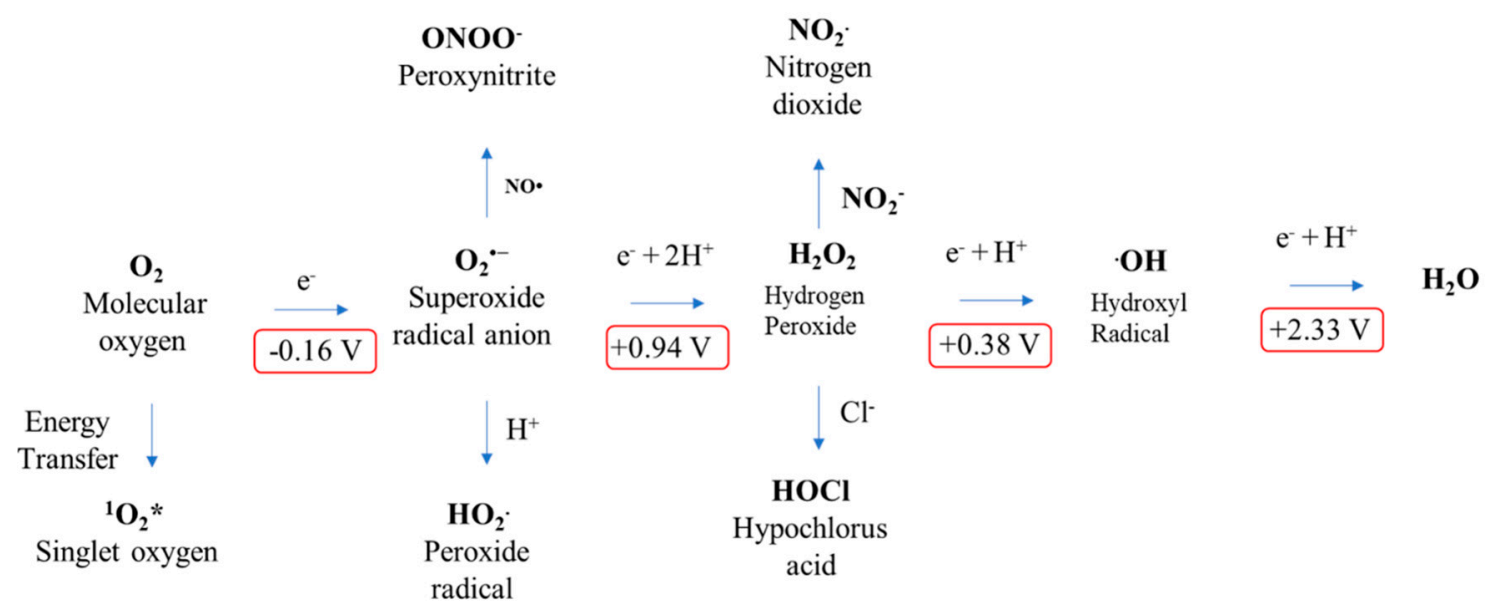

Figure 3. Standard reduction potentials of ROS formation via energy or electron transfer reactions of molecular oxygen.

\section{ROS Generating Agents in Tauopathies}

\subsection{Tau Aggregation}

Tau aggregate is one of the primary culprits in tauopathies. There is clear evidence among OS with tau hyperphosphorylation, polymerization, and toxicity in both animal models and patients [11]. OS produces oxidized fatty acids that stimulate in vitro tau polymerization [54]. Also, the overexpressed tau protein showed increased OS in N2a cultured cells [31]. Besides, rat cortical neurons from truncated tau expressing transgenic rats showed an increased level of ROS [55]. This evidence suggests that OS directly promotes tau aggregation, and inversely toxic tau species stimulate OS conditions in tauopathies.

\subsection{Amyloid-Beta Aggregation}

Amyloid-beta $(A \beta)$ aggregation is another pathogenic event in tauopathies. Numerous studies have shown that OS promotes $A \beta$ production by diminishing $\alpha$-secretase activity and increasing $\beta$ and $\gamma$-secretase activity [56]. The AD mouse model (Tg2576-APP-PS1) has enhanced OS due to increasing $\mathrm{H}_{2} \mathrm{O}_{2}$ levels and the peroxidation of proteins and lipids [57]. Oppositely, the accumulation of $A \beta$ increases OS and leads to memory dysfunction in the AD mouse (Tg2576-APP) [58] and mitochondrial failure in the early stages of $\mathrm{AD}[30]$.

\subsection{Metals}

Copper $(\mathrm{Cu})$, zinc $(\mathrm{Zn})$ and iron $(\mathrm{Fe})$ are the three most abundant metals in mammalian brains, which regulate many synaptic functions. Aberrant homeostasis of these metals, like their levels, mislocalization, and dysregulation, was evidenced in the hippocampus and amygdala of $\mathrm{AD}$ patients [59]. In addition, aluminum $\left(\mathrm{Al}^{3+}\right)$ is also associated with oxidative stress leading to $\mathrm{AD}[60]$. 


\subsection{Inflammation}

Neuro-inflammation is expected in sites of metal deposition. Neuro-inflammation is followed by the production of reactive compounds by microglial cells. The microglia can be activated by several factors, including $\mathrm{A} \beta$. Activated microglia play a role in AD onset by increased ROS burden and oxidative stress [61].

\subsection{Anti-Oxidant}

Glutathione, uric acid, vitamin C and E, or antioxidant enzymes (superoxide dismutase, catalase, etc.) are lower in $\mathrm{AD}$ patients [30,62]. Failure of the antioxidant defense systems induces OS that is facilitated by $A \beta$ depositions in AD mice with the APP mutation [30].

\section{Evaluation of ROS in Tauopathies}

Since OS is related to the pathophysiological mechanism in tauopathies (Figure 4), several surrogate markers for ROS have been assessed. The measuring parameters mainly cover peroxides including nucleic acid (8-OGH and 8-OHdG, protein or lipid (malondialdehyde, MDA or 4-hydroxynonenal, 4-HNE), antioxidant enzymes, superoxide dismutase (cytosolic SOD1 or mitochondrial SOD2), glutathione levels, glutathione $S$ transferase (GST), heme Oxygenase-1 (HO-1), homocysteine (Hcy) levels, F2-isoprostanes (F2-IsoPs) and vitamins (A, C, or E). These markers are elevated or depleted in particular brain regions of the same patient in tauopathies. A table (Table 1) is provided here based on the available literature for potential OS markers in assessing tauopathies.

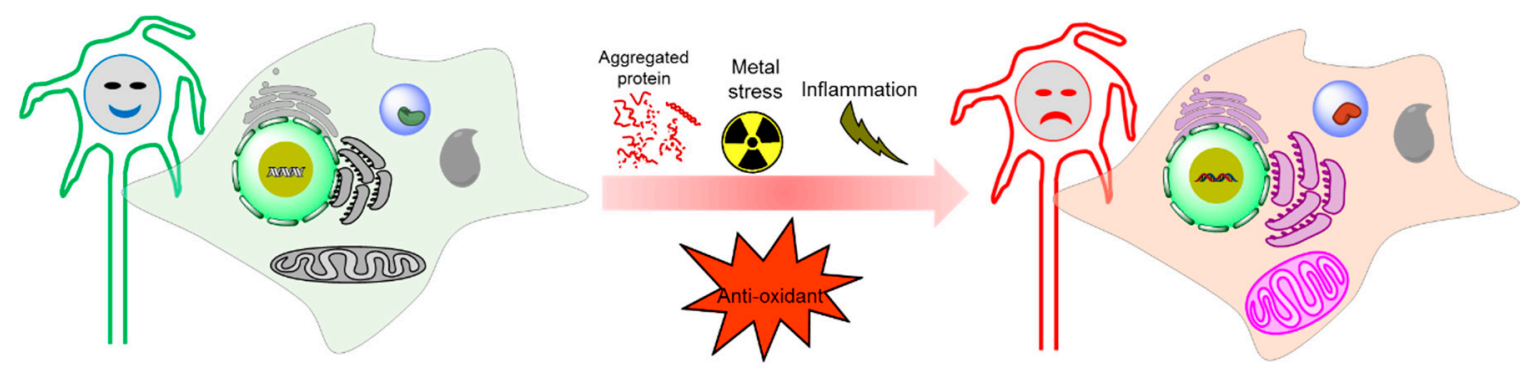

Figure 4. Physiological condition versus tauopathy condition by oxidative stress generation. 
Table 1. Potential oxidative markers in tauopathies (up-regulation is labeled as up-arrow, and down-regulation is labeled as down-arrow).

\begin{tabular}{|c|c|c|c|c|c|c|c|c|}
\hline OS Markers & $\mathrm{AD}$ & PSP & PiD & CBD & FTD & FTDP-17 & FTLD & PD \\
\hline SOD1 & $\begin{array}{l}\downarrow[27] \\
\uparrow[63]\end{array}$ & $\uparrow[11]$ & & & & & $\uparrow[64]$ & $\uparrow[63]$ \\
\hline SOD2 & $\begin{array}{l}\downarrow[27] \\
\uparrow[65]\end{array}$ & $\uparrow[11]$ & & & & $\downarrow[66]$ & $\uparrow[64]$ & $\uparrow[67]$ \\
\hline $\mathrm{Cu} / \mathrm{Zn}-\mathrm{SOD}$ & $\begin{array}{l}\downarrow[27] \\
\uparrow[68]\end{array}$ & $\uparrow[11]$ & & & & & & $\uparrow[63]$ \\
\hline GSH & $\downarrow[27]$ & $\begin{array}{l}\uparrow[69] \\
\downarrow[70]\end{array}$ & & & & & $\downarrow[64]$ & $\downarrow[69]$ \\
\hline GST & $\downarrow[71]$ & & & & & $\downarrow[11]$ & & \\
\hline Catalase & $\downarrow[72]$ & & & & & & & $\downarrow[73]$ \\
\hline GPx & $\begin{array}{l}\downarrow[72] \\
\uparrow[74] \\
\end{array}$ & $\uparrow[75]$ & & & & $\begin{array}{l}\uparrow[11] \\
\downarrow[11]\end{array}$ & & $\begin{array}{l}\uparrow[76] \\
\downarrow[67]\end{array}$ \\
\hline Lipid peroxidase & $\uparrow[27]$ & $\uparrow[77]$ & & & $\uparrow[78]$ & & & $\uparrow[79]$ \\
\hline MDA & $\uparrow[27]$ & $\uparrow[80]$ & & & & & $\uparrow[64]$ & $\uparrow[81]$ \\
\hline 4-HNE & $\uparrow[27]$ & $\uparrow[75]$ & $\uparrow[81]$ & & & & $\uparrow[64]$ & $\uparrow[82]$ \\
\hline Vitamin A & $\downarrow[83]$ & & & & & & & \\
\hline Vitamin C & $\downarrow[84]$ & & & & & & & $\downarrow[73]$ \\
\hline Vitamin E & $\downarrow[85]$ & & & & & & & $\downarrow[73]$ \\
\hline HO-1 & $\uparrow[86]$ & $\uparrow[86]$ & $\uparrow[86]$ & $\uparrow[86]$ & $\uparrow[78]$ & & & $\uparrow[87]$ \\
\hline Protein carbonyl & $\uparrow[27]$ & & & & $\uparrow[78]$ & & & $\uparrow[63]$ \\
\hline 3-nitrotyrosine & $\uparrow[27]$ & & & & & & & $\uparrow[88]$ \\
\hline 8-OHG & $\uparrow[27]$ & & & & & & & $\uparrow[89]$ \\
\hline 8-OHdG & $\uparrow[27]$ & & & & & & & $\uparrow[89]$ \\
\hline F2-IsoPs & $\uparrow[27]$ & & & & & & & \\
\hline Hcy & $\uparrow[90]$ & & & & & & & \\
\hline $\operatorname{cox}$ & $\uparrow[91]$ & & & & & & & \\
\hline PDHC & $\downarrow[92]$ & & & & & & & \\
\hline KGDHC & $\downarrow[93]$ & & & & & & & \\
\hline
\end{tabular}

\section{Fluorescence Probes for ROS Detection}

Fluorescent probes have advantages for high sensitivity and selectivity over other techniques. Combined with fluorescent microscopy, the fluorescent probes can be used to visualize analytes in living cells spatiotemporally. Also, this technique is fast and straightforward, without a unique facility or high cost-efficiency. Fluorescent sensors (organic fluorophores), when recognizing the target molecule, tend to change their fluorescence emission intensity or color [94-97]. Here we would like to emphasize some of the basic concepts of the ROS probing based on the fluorescent technique (Table 2).

Fluorescent probes for hydrogen peroxide are mainly based on boronate esters via the $\mathrm{H}_{2} \mathrm{O}_{2}$-induced oxidation of arylboronate ester to phenols [98-100]. It is known that under mild alkaline conditions $\mathrm{H}_{2} \mathrm{O}_{2}$ reacts with arylboronic acids and arylboronate ester to produce phenols [101].

Most of the probes for the superoxide radical are based on reaction-based mechanisms, where the superoxide will react with a probe to generate a new molecule with a different fluorescence intensity or color of the probe. These probes are based on superoxide-induced oxidation reactions and reactions with nitroxide [102]. Another essential feature of the superoxide is strong nucleophilicity, where it is known as a super nucleophile. Due to this inherent property, fluorescent probes for superoxide are mainly based on nucleophilic substitution reaction [103]. In this case, most of the time, the leaving group is from the phosphinate group [104], triflate group [105], 2,4-dinitrobenzenesulfonyl [106], 
nitro-ethers [107], and related groups. Recently, a sulfinate-based chemosensor for superoxide sensing was reported to reduce the molecular size, with good solubility and a cLogP value of 3.8 [108].

Detection of the hydroxyl radical is very challenging due to its low concentration. It is the most reactive among the various classes of the ROS. The hydroxyl radical can oxidize most of the biomolecules like carbohydrates, proteins, and nucleic acids. One of the main classes for hydroxyl radical detection is the oxidation of leuco forms of fluorescent dyes (cyanine, 2,7-dichlorodihydrofluorescein, and dihydrorhodamine) mediated by hydroxyl radical. These probes become highly fluorescent upon reaction with a hydroxyl radical by recovering the $\pi$-conjugation networks through hydrogen atom abstraction, and subsequently one-electron oxidation [109-112]. Some of the nitroxides have been exploited as fluorescent probes for hydroxyl radicals. Here, the diamagnetization reaction between nitroxide and radical restores the fluorescence intensity was exploited, where the $\mathrm{CH}_{3}$ radical (generated from hydroxyl radical and dimethyl sulfoxide, DMSO) reacts with the nitroxide moiety to produce the diamagnetic adduct $[95,113]$.

Singlet oxygen is produced by energy transfer from $\mathrm{O}_{2}$. As a result, singlet oxygen has paired electrons with opposite spin (spin-restriction state) which enhance oxidizing ability when compared with molecular oxygen. The fluorescent probes for singlet oxygen have been developed based on $[2+4]$ cycloaddition, where singlet oxygen acts as a strong dienophile $[109,114,115]$.

Most of the probes for peroxynitrite are based on the organic reactions of probes with peroxynitrite. These reactions include the oxidation of chalcogenides, boronic acids or boronates, hydrazides, the cleavage of $\mathrm{C}-\mathrm{C}$ double bonds, and oxidative $\mathrm{N}$-dearylation $[116,117]$. Among these, the most common reaction is the oxidation of chalcogenides (S, Se, and Te) [118,119].

Different types of functional groups have been studied for the detection of NO, which are o-diamino aromatic compounds, luminescent lanthanide complexes, transition-metal complexes, quantum dots, and carbon nanotube sensors. The most commonly studied method for the detection of NO is based on the reaction of a O-diaminophenyl group with NO to generate triazole [120,121].

The fluorescent probes for hypochlorite are mostly based on xanthene probes. The mechanism behind this sensing is the spiro-ring opening of the xanthene probes, which react with hypochlorite [95]. Also, some of the probes are based on the oxidation of catechol to benzoquinone [122].

Apart from these probes, some of the fluorescent probes for the detection of ROS are reported in Alzheimer's disease. An oxalate-curcumin-based probe was reported for the imaging of reactive oxygen species in AD. Here, the oxalate moiety was utilized, which reacts with $\mathrm{H}_{2} \mathrm{O}_{2}$ to produce the fluorescence signal with a shift in wavelength [123-126]. A bifunctional fluorescent probe based on the benzothiazole core has been reported for $\mathrm{H}_{2} \mathrm{O}_{2}$ and amyloid aggregate detection. The probe is a combination of benzothiazole and a boronate ester [127]. 
Table 2. ROS and their mode of detection using fluorescent probes.

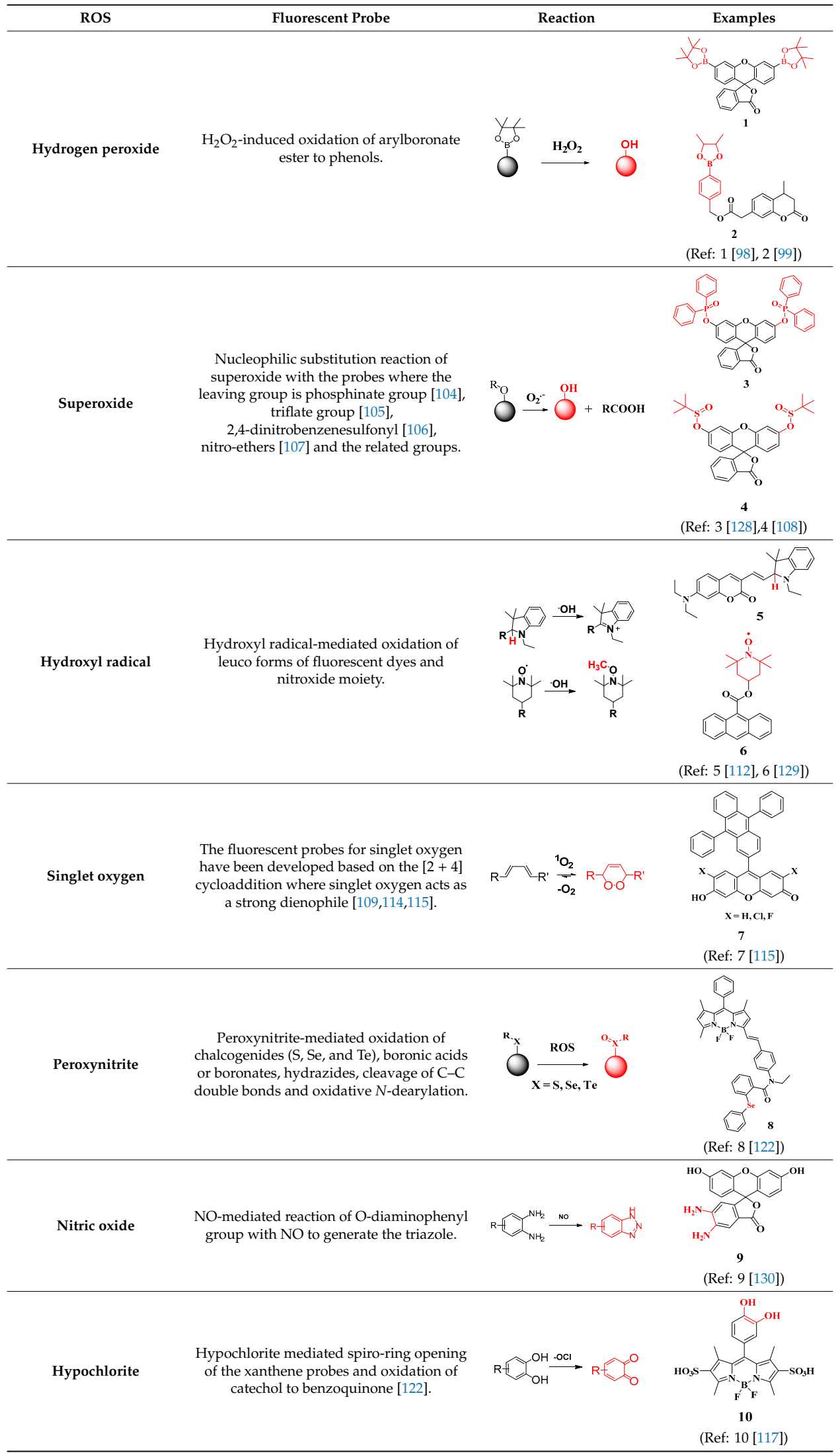




\section{Controlling of ROS as Therapeutic Approaches of Tauopathies}

Despite the unmet needs for the treatment of tauopathies, FDA-approved treatments are limited to alleviate memory deficits and behavioral changes. Despite the fact that extensive drug discovery programs have been conducted over previous decades, there are still no convincing drugs. Some drugs have adverse side effects or exhibit a lack of cognitive improvement in trial participants. For these reasons, new strategies for therapeutic pathways are being considered. Potent pieces of evidence for the imbalance phenomena of oxidants/antioxidants in AD led to the hypothesis that compounds scavenging free radicals or upregulating the OS defense mechanism might provide therapeutic approaches for AD (Table 3).

\subsection{Antioxidant Pathway}

By reviewing the OS theories in tauopathies, several therapeutic approaches have been conducted in different tauopathies. Curcumin, found in turmeric, is an antioxidant that decreases $A \beta$-induced tau hyperphosphorylation in PC12 cells. It also protects PC12 cells through the inhibition of OS [131]. Another class of antioxidant, methylene blue (methylthioninium chloride, MB), which can penetrate the blood brain barrier, diminished oxidized nucleic acids and tau hyperphosphorylation in tau ${ }^{\mathrm{P} 301 \mathrm{~S}}$ transgenic mice [132]. Administration of coenzyme Q10 (CoQ10; a critical member in electron transport chain), which has antioxidant effects, can significantly reduce tau phosphorylation, lipid peroxidation and OS, while ameliorating behavioral deficits and the survival rate of tau ${ }^{\mathrm{P} 301 \mathrm{~S}}$ transgenic mice [133]. The overexpression of thioredoxin peroxidase, an antioxidant enzyme, worsens disease phenotypes of $\mathrm{tau}^{\mathrm{R} 406 \mathrm{~W}}$ transgenic drosophila [66]. In PD mice, sulforaphane (found in cruciferous vegetables) were found to be effective at protecting dopaminergic neurons and enhancing GSH levels [134]. Brilliant blue $G$, an antagonist of the P2X7R pathway of several neurodegeneration, can cross the blood brain barrier to ameliorate neuropathology in AD and PD mouse models [135].

\subsection{Catalase}

Catalase, located in peroxisomes, cytoplasm, and mitochondria, is responsible for $\mathrm{H}_{2} \mathrm{O}_{2}$ conversion into water and oxygen by using iron or manganese as a cofactor. The administration of $\mathrm{SOD} /$ catalase mimetic EUK-207 deteriorates disease phenotypes by reducing phosphorylated tau and lipid peroxidation in 3xTg-AD mice [136].

\subsection{Vitamin}

Cells and animal studies, as well as clinical studies, have shown a particular connection between vitamins and tauopathies. The antioxidant activities of vitamins may be useful for the treatment of tauopathies. Proper supplementation of vitamins can reduce the tauopathy incidence in the general population and improve the state of patients. Vitamin $C$ is a water-soluble antioxidant that is abundant in vegetables, fruits, and animal livers. It involves in the inhibition of OS, reducing lipid peroxidation, the exclusion of free radicals, and acts as a cofactor for antioxidant enzymes [137]. Vitamin E is a lipid-soluble high antioxidant which can diminish the effects of peroxide, also protecting against lipid peroxidation in cell membranes. Vitamin C (ascorbic acid), when used to treat primary corticohippocampal neurons from tau transgenic rats (Tau ${ }^{151-391} 4 \mathrm{R}$ ), decreased ROS levels in the neurons, tau inclusions in the spinal cord, and improved behavior [138]. Supplementation of vitamin $\mathrm{E}$ ( $\alpha$-tocopherol) delayed tau pathology by attenuating motor weakness in the tau mouse model (B6D2/F1-Tau44) [139]. A recent study has shown that omega-3 fatty acids plus vitamin E supplementation can improve total antioxidant capacity and GSH levels in PD patients [140]. 
Table 3. Therapeutic approaches of tauopathies related to ROS.

\begin{tabular}{|c|c|c|c|c|}
\hline $\begin{array}{l}\text { Therapeutic } \\
\text { Approaches }\end{array}$ & Chemical Agents & Treating Route and Doses & Experimental Model & Reference \\
\hline \multirow{8}{*}{$\begin{array}{l}\text { Antioxidant } \\
\text { pathway }\end{array}$} & Curcumin & $10 \mu \mathrm{g} / \mathrm{mL}$ for $1 \mathrm{~h}$ & $\mathrm{~A} \beta$ treated $\mathrm{PC} 12$ cell & [131] \\
\hline & Methylene blue & $4 \mathrm{mg} / \mathrm{kg}$ in diet & $\mathrm{Tau}^{\mathrm{P} 301 \mathrm{~S}}$ mouse & [132] \\
\hline & CoQ10 & $0.5 \%$ in diet & $\mathrm{Tau}^{\mathrm{P} 301 \mathrm{~S}}$ mouse & [133] \\
\hline & Paraquant & $30 \mathrm{mM}$ in diet for $48 \mathrm{~h}$ & $\mathrm{Tau}^{\mathrm{R} 406 \mathrm{~W}}$ drosophila & {$[66]$} \\
\hline & Sulforaphane & $\begin{array}{l}5 \mathrm{mg} / \mathrm{kg} \text { twice a week by } \\
\text { intraperitoneally }\end{array}$ & C57Bl $/ 6^{6-\mathrm{OHDA}}$ mouse & [134] \\
\hline & BR 297 & $500 \mathrm{nM}$ for $24 \mathrm{~h}$ & APP treated SH-SY5Y cell & [145] \\
\hline & S14 & $\begin{array}{l}5 \mathrm{mg} / \mathrm{Kg} / \text { daily for } 4 \text { weeks } \\
\text { by intraperitoneally }\end{array}$ & $\operatorname{Tg} 2576^{\mathrm{APP} / P S 1}$ AD mouse & [146] \\
\hline & Resveratrol & $\begin{array}{l}500-1000 \mathrm{mg} / \text { daily for } 26 \\
\text { months by orally }\end{array}$ & $\mathrm{AD}$ patients & [147] \\
\hline Catalase & EUK-207 & $\begin{array}{l}3.41 \mathrm{mM} / \text { day for } 28 \text { days } \\
\text { by micro-osmotic pump }\end{array}$ & C57BL/6/129S-3xTg-AD mouse & [136] \\
\hline \multirow{5}{*}{ Vitamin } & Ascorbic acid & $250-500 \mu \mathrm{M}$ for $24 \mathrm{~h}$ & Neurons form Tau ${ }^{151-391}$ rat & [138] \\
\hline & \multirow{3}{*}{$\alpha$-tocopherol } & $\begin{array}{l}0.5-1.5 \mathrm{mM} \text { in diet for } 10 \\
\text { days }\end{array}$ & tau $^{\mathrm{R} 406 \mathrm{~W}}$ drosophila & [66] \\
\hline & & $49 \mathrm{IU} / \mathrm{Kg}$ in diet & B6D2/F1-tau44 mouse & [139] \\
\hline & & $2000 \mathrm{IU} /$ day for 6 months & AD patient & [148] \\
\hline & Tocotrienol & $\begin{array}{l}5 \mathrm{mg} / \mathrm{Kg} / \text { day for } 15 \\
\text { months by orally }\end{array}$ & APPswe/PS1dE9 mouse & [149] \\
\hline \multirow{4}{*}{ Metal chelator } & Clioquinol & $\begin{array}{l}30 \mathrm{mg} / \mathrm{kg} / \text { day for } 5 \text { weeks } \\
\text { by orally }\end{array}$ & TgCRND8-AD mouse & [141] \\
\hline & PBT2 & $\begin{array}{l}250 \mathrm{mg} / \text { day for } 12 \text { weeks } \\
\text { by orally }\end{array}$ & AD patient & [142] \\
\hline & $\mathrm{Cu}^{\mathrm{II}} \mathrm{GTSM}$ & $10 \mathrm{mg} / \mathrm{kg} /$ daily by orally & APP/PS1 AD mouse & [143] \\
\hline & Desferrioxamine & $\begin{array}{l}125 \mathrm{mg} \text { twice daily } / 5 \text { days } \\
\text { per week for } 24 \text { months by } \\
\text { intramuscularly }\end{array}$ & AD patient & [144] \\
\hline
\end{tabular}

\subsection{Metal Chelator}

Alterations in metallostasis (mainly $\mathrm{Zn}, \mathrm{Cu}$ and $\mathrm{Fe}$ ) are responsible for AD. So, ionophore addition would be another treatment choice by restoring ion balances. Clioquinol (5-chloro-7-iodo-quinoline-8-ol) is a moderate chelator for $\mathrm{Cu}, \mathrm{Zn}$, and Fe that rescued memory impairment in the TgCRND8-AD mouse after oral administration [141]. The second generation of clioquinol is PBT2, which is now in a clinical trial (phase II) [142]. Both of their modes of action probably rely on copper ionophore activity. Based on this mechanism, another copper containing chelator, CuII GTSM [bis(thiosemicarbazone)], was developed, which could change GSK-3 $\beta$ activity, tau phosphorylation, and restore cognitive impairment in APP/PS1 transgenic mice [143]. One Fe chelator, desferrioxamine, was intramuscularly injected into AD patients, slowing the clinical progression of dementia [144].

\section{Conclusions}

Oxidative stress contributes to the development of tauopathies. It forms vicious pathophysiology inducing mitochondrial dysfunctions, neuronal damages and promotes metal toxicity. The complex nature, genesis, and responses of ROS in tauopathies are still actively being investigated. At the cellular level, individual cells generate excessive levels of ROS, followed by a dysfunctional state of mitochondria that interacts with redox metals and oxidative stress-responsive elements. Although the formation of ROS poses a threat to tauopathies, compensatory responses provoked by ROS removal or the prevention of the ROS generation pathway may interrupt the onset or slow down the progression of tauopathies through multiple mechanisms. These mechanisms include the reduction of oxidative stress-mediated neuronal toxicity, a decrease of tau phosphorylation and aggregation, restoration of mitochondrial function, and metal homeostasis. Therefore, treatment with antioxidants could be an 
alternative approach to target molecular events implicated in tauopathies. However, evidence on antioxidants as potential therapeutic agents for tauopathies has not been carried out to a significant level. Hence, a more in-depth understanding of OS in tauopathies is in high demanded.

Funding: This work was supported by the National Research Foundation (NRF-2018M3A9H4079286), Brain Research Program (2016M3C7A1913845), and the National Research Council of Science and Technology (NST) (No. CRC-15-04-KIST) funded by the Ministry of Science, ICT \& Future Planning. Dr. Haque is a recipient of the Korea Research Fellowship Program through the National Research Foundation of Korea (NRF) (NRF-2018H1D3A1A02074556).

Conflicts of Interest: The authors declare no conflict of interest.

\section{Abbreviations}

\begin{tabular}{|c|c|}
\hline$\bullet \mathrm{OH}$ & Hydroxyl radical \\
\hline${ }^{1} \mathrm{O}_{2}$ & Singlet oxygen \\
\hline 8-OHdG & 8-Hydroxy-2'-deoxyguanosine \\
\hline 8-OHG & 8-Hydroxy-2'-guanosine \\
\hline $\mathrm{A} \beta$ & Amyloid beta' Abeta \\
\hline $\mathrm{AD}$ & Alzheimer's disease \\
\hline $\mathrm{Al}$ & Aluminium \\
\hline ATP & Adenosine triphosphate \\
\hline CBD & Corticobasal degeneration \\
\hline CNS & Central nervous system \\
\hline $\mathrm{CO}_{3} \bullet-$ & Carbonate radical \\
\hline CoQ10 & Coenzyme Q10 \\
\hline $\mathrm{COX}$ & Cytochrome oxidase \\
\hline $\mathrm{Cu}$ & Copper \\
\hline DMSO & Dimethyl sulfoxide \\
\hline ER & Endoplasmic reticulum \\
\hline ETC & Electron transport chain \\
\hline FDA & US Food and Drug Administration \\
\hline $\mathrm{Fe}$ & Iron \\
\hline FTD & Frontotemporal dementia \\
\hline FTDP-17 & FTD with parkinsonism linked to chromosome-17 \\
\hline FTLD & Frontotemporal lobar degeneration \\
\hline GPx & Glutathione peroxidase \\
\hline GSH & Glutathione \\
\hline GST & Glutathione $S$ transferase \\
\hline $\mathrm{H}_{2} \mathrm{O}_{2}$ & Hydrogen peroxide \\
\hline Hcy & Homocysteine \\
\hline 4-HNE & 4-Hydroxynonenal \\
\hline $\mathrm{HO}-1$ & Heme oxygenase-1 \\
\hline $\mathrm{HO}_{2}$ & Hydroperoxyl radical \\
\hline $\mathrm{HOBr}$ & Hypobromous \\
\hline $\mathrm{HOCl}$ & Hypochlorous \\
\hline HOI & Hypoiodous acids \\
\hline $\mathrm{Hr}$ & Hour \\
\hline KGDHC & $\alpha$-Ketogluterate dehydrogenase complex \\
\hline MAPK & Mitogen-activated protein kinase \\
\hline $\mathrm{MB}$ & Methylene blue; methylthioninium chloride \\
\hline
\end{tabular}




\begin{tabular}{|c|c|}
\hline NFT & Neurofibrillary tangle \\
\hline $\mathrm{NO}$ or $\mathrm{NO} \bullet$ & Nitric oxide radical \\
\hline $\mathrm{NO}_{2}-$ & Nitrite \\
\hline $\mathrm{NO}_{2} \bullet$ & Nitrogen dioxide radical \\
\hline $\mathrm{O}_{2}^{-}$or $\mathrm{O}_{2} \bullet^{-}$ & Superoxide anion radical \\
\hline $\mathrm{O}_{3}$ & Ozone \\
\hline ONOO- & Peroxynitrite \\
\hline OS & Oxidative stress \\
\hline PD & Parkinson's disease \\
\hline PDHC & Pyruvate dehydrogenase complex \\
\hline PiD & Pick's disease \\
\hline PSP & Progressive supranuclear palsy \\
\hline PTM & Posttranslational modification \\
\hline RNS & Reactive nitrogen species \\
\hline $\mathrm{RO \bullet}$ & Alkoxyl radical \\
\hline ROI & Reactive oxygen intermediate \\
\hline ROO• & Peroxyl radical \\
\hline ROS & Reactive oxygen species \\
\hline SOD & Superoxide dismutase \\
\hline SQ•- & Semiquinone radical \\
\hline $\mathrm{Zn}$ & Zinc \\
\hline
\end{tabular}

\section{References}

1. Shin, R.W.; Iwaki, T.; Kitamoto, T.; Tateishi,J. Hydrated autoclave pretreatment enhances tau immunoreactivity in formalin-fixed normal and Alzheimer's disease brain tissues. Lab. Investig. 1991, 64, 693-702.

2. Cleveland, D.W.; Hwo, S.Y.; Kirschner, M.W. Physical and chemical properties of purified tau factor and the role of tau in microtubule assembly. J. Mol. Biol. 1977, 116, 227-247. [CrossRef]

3. Kolarova, M.; Garcia-Sierra, F.; Bartos, A.; Ricny, J.; Ripova, D. Structure and pathology of tau protein in Alzheimer disease. Int. J. Alzheimers Dis. 2012, 2012, 731526. [CrossRef]

4. Mazanetz, M.P.; Fischer, P.M. Untangling tau hyperphosphorylation in drug design for neurodegenerative diseases. Nat. Rev. Drug Discov. 2007, 6, 464-479. [CrossRef] [PubMed]

5. Miyata, Y.; Hoshi, M.; Nishida, E.; Minami, Y.; Sakai, H. Binding of microtubule-associated protein 2 and tau to the intermediate filament reassembled from neurofilament 70-kDa subunit protein. Its regulation by calmodulin. J. Biol. Chem. 1986, 261, 13026-13030.

6. Jung, D.; Filliol, D.; Miehe, M.; Rendon, A. Interaction of brain mitochondria with microtubules reconstituted from brain tubulin and MAP2 or TAU. Cell Motil. Cytoskeleton 1993, 24, 245-255. [CrossRef]

7. Mandelkow, E.M.; Stamer, K.; Vogel, R.; Thies, E.; Mandelkow, E. Clogging of axons by tau, inhibition of axonal traffic and starvation of synapses. Neurobiol. Aging 2003, 24, 1079-1085. [CrossRef] [PubMed]

8. Obulesu, M.; Venu, R.; Somashekhar, R. Tau mediated neurodegeneration: An insight into Alzheimer's disease pathology. Neurochem. Res. 2011, 36, 1329-1335. [CrossRef] [PubMed]

9. Buee, L.; Bussiere, T.; Buee-Scherrer, V.; Delacourte, A.; Hof, P.R. Tau protein isoforms, phosphorylation and role in neurodegenerative disorders. Brain Res. Brain Res. Rev. 2000, 33, 95-130. [CrossRef]

10. Spillantini, M.G.; Goedert, M. Tau pathology and neurodegeneration. Lancet Neurol. 2013, 12, 609-622. [CrossRef]

11. Alavi Naini, S.M.; Soussi-Yanicostas, N. Tau Hyperphosphorylation and Oxidative Stress, a Critical Vicious Circle in Neurodegenerative Tauopathies? Oxid. Med. Cell Longev. 2015, 2015, 151979. [CrossRef]

12. Zhang, X.; Gao, F.; Wang, D.; Li, C.; Fu, Y.; He, W.; Zhang, J. Tau Pathology in Parkinson's Disease. Front. Neurol. 2018, 9, 809. [CrossRef] [PubMed]

13. Haque, M.M.; Kim, D.; Yu, Y.H.; Lim, S.; Kim, D.J.; Chang, Y.T.; Ha, H.H.; Kim, Y.K. Inhibition of tau aggregation by a rosamine derivative that blocks tau intermolecular disulfide cross-linking. Amyloid 2014, 21, 185-190. [CrossRef] [PubMed]

14. Lim, S.; Haque, M.M.; Kim, D.; Kim, D.J.; Kim, Y.K. Cell-based Models To Investigate Tau Aggregation. Comput. Struct. Biotechnol. J. 2014, 12, 7-13. [CrossRef] [PubMed]

15. Carrell, R.W.; Gooptu, B. Conformational changes and disease-Serpins, prions and Alzheimer's. Curr. Opin. Struct. Biol. 1998, 8, 799-809. [CrossRef] 
16. Binder, L.I.; Guillozet-Bongaarts, A.L.; Garcia-Sierra, F.; Berry, R.W. Tau, tangles, and Alzheimer's disease. Biochim. Biophys. Acta 2005, 1739, 216-223. [CrossRef] [PubMed]

17. Schweers, O.; Mandelkow, E.M.; Biernat, J.; Mandelkow, E. Oxidation of cysteine-322 in the repeat domain of microtubule-associated protein tau controls the in vitro assembly of paired helical filaments. Proc. Natl. Acad. Sci. USA 1995, 92, 8463-8467. [CrossRef] [PubMed]

18. Wischik, C.M.; Novak, M.; Edwards, P.C.; Klug, A.; Tichelaar, W.; Crowther, R.A. Structural characterization of the core of the paired helical filament of Alzheimer disease. Proc. Natl. Acad. Sci. USA 1988, 85, 4884-4888. [CrossRef]

19. Groeger, G.; Quiney, C.; Cotter, T.G. Hydrogen peroxide as a cell-survival signaling molecule. Antioxid. Redox Signal. 2009, 11, 2655-2671. [CrossRef]

20. Patten, D.A.; Germain, M.; Kelly, M.A.; Slack, R.S. Reactive oxygen species: Stuck in the middle of neurodegeneration. J. Alzheimers Dis. 2010, 20 (Suppl. 2), S357-S367. [CrossRef]

21. Dasuri, K.; Zhang, L.; Keller, J.N. Oxidative stress, neurodegeneration, and the balance of protein degradation and protein synthesis. Free Radic. Biol. Med. 2013, 62, 170-185. [CrossRef]

22. Ray, P.D.; Huang, B.W.; Tsuji, Y. Reactive oxygen species (ROS) homeostasis and redox regulation in cellular signaling. Cell Signal. 2012, 24, 981-990. [CrossRef]

23. Kim, G.H.; Kim, J.E.; Rhie, S.J.; Yoon, S. The Role of Oxidative Stress in Neurodegenerative Diseases. Exp. Neurobiol. 2015, 24, 325-340. [CrossRef]

24. Wang, X.; Michaelis, E.K. Selective neuronal vulnerability to oxidative stress in the brain. Front. Aging Neurosci. 2010, 2, 12. [CrossRef]

25. Ferreira, M.E.; de Vasconcelos, A.S.; da Costa Vilhena, T.; da Silva, T.L.; da Silva Barbosa, A.; Gomes, A.R.; Dolabela, M.F.; Percario, S. Oxidative Stress in Alzheimer's Disease: Should We Keep Trying Antioxidant Therapies? Cell Mol. Neurobiol. 2015, 35, 595-614. [CrossRef] [PubMed]

26. Zhu, X.; Lee, H.G.; Casadesus, G.; Avila, J.; Drew, K.; Perry, G.; Smith, M.A. Oxidative imbalance in Alzheimer's disease. Mol. Neurobiol. 2005, 31, 205-217. [CrossRef]

27. Chen, Z.; Zhong, C. Oxidative stress in Alzheimer's disease. Neurosci. Bull. 2014, 30, 271-281. [CrossRef]

28. Jiang, T.; Sun, Q.; Chen, S. Oxidative stress: A major pathogenesis and potential therapeutic target of antioxidative agents in Parkinson's disease and Alzheimer's disease. Prog. Neurobiol. 2016, 147, 1-19. [CrossRef]

29. Resende, R.; Moreira, P.I.; Proenca, T.; Deshpande, A.; Busciglio, J.; Pereira, C.; Oliveira, C.R. Brain oxidative stress in a triple-transgenic mouse model of Alzheimer disease. Free Radic. Biol. Med. 2008, 44, 2051-2057. [CrossRef]

30. Zhao, Y.; Zhao, B. Oxidative stress and the pathogenesis of Alzheimer's disease. Oxid. Med. Cell Longev. 2013, 2013, 316523. [CrossRef]

31. Stamer, K.; Vogel, R.; Thies, E.; Mandelkow, E.; Mandelkow, E.M. Tau blocks traffic of organelles, neurofilaments, and APP vesicles in neurons and enhances oxidative stress. J. Cell Biol. 2002, 156, 1051-1063. [CrossRef]

32. Yoshiyama, Y.; Higuchi, M.; Zhang, B.; Huang, S.M.; Iwata, N.; Saido, T.C.; Maeda, J.; Suhara, T.; Trojanowski, J.Q.; Lee, V.M. Synapse loss and microglial activation precede tangles in a P301S tauopathy mouse model. Neuron 2007, 53, 337-351. [CrossRef]

33. David, D.C.; Hauptmann, S.; Scherping, I.; Schuessel, K.; Keil, U.; Rizzu, P.; Ravid, R.; Drose, S.; Brandt, U.; Muller, W.E.; et al. Proteomic and functional analyses reveal a mitochondrial dysfunction in P301L tau transgenic mice. J. Biol. Chem. 2005, 280, 23802-23814. [CrossRef]

34. Butterfield, D.A.; Swomley, A.M.; Sultana, R. Amyloid beta-peptide (1-42)-induced oxidative stress in Alzheimer disease: Importance in disease pathogenesis and progression. Antioxid. Redox Signal. 2013, 19, 823-835. [CrossRef]

35. Ashabi, G.; Ahmadiani, A.; Abdi, A.; Abraki, S.B.; Khodagholi, F. Time course study of Abeta formation and neurite outgrowth disruption in differentiated human neuroblastoma cells exposed to $\mathrm{H} 2 \mathrm{O} 2$ : Protective role of autophagy. Toxicol. In Vitro 2013, 27, 1780-1788. [CrossRef]

36. Hauser, D.N.; Hastings, T.G. Mitochondrial dysfunction and oxidative stress in Parkinson's disease and monogenic parkinsonism. Neurobiol. Dis. 2013, 51, 35-42. [CrossRef]

37. Nathan, C.; Ding, A. SnapShot: Reactive oxygen intermediates (ROI). Cell 2010, 140, 951-951.e2. [CrossRef] [PubMed]

38. Krumova, K.; Cosa, G. Overview of reactive oxygen species. Singlet Oxygen: Appl. Biosci. Nanosci. 2016, 1, 1-21.

39. Murphy, M.P. How mitochondria produce reactive oxygen species. Biochem. J. 2009, 417, 1-13. [CrossRef] 
40. Dickinson, B.C.; Chang, C.J. Chemistry and biology of reactive oxygen species in signaling or stress responses. Nat. Chem. Biol. 2011, 7, 504. [CrossRef]

41. Chong, W.; Shastri, M.; Eri, R. Endoplasmic reticulum stress and oxidative stress: A vicious nexus implicated in bowel disease pathophysiology. Int. J. Mol. Sci. 2017, 18, 771. [CrossRef] [PubMed]

42. Walling, C. Fenton's reagent revisited. Acc. Chem. Res. 1975, 8, 125-131. [CrossRef]

43. Imlay, J.A. Pathways of oxidative damage. Annu. Rev. Microbiol. 2003, 57, 395-418. [CrossRef] [PubMed]

44. D'Autréaux, B.; Toledano, M.B. ROS as signalling molecules: Mechanisms that generate specificity in ROS homeostasis. Nat. Rev. Mol. Cell Biol. 2007, 8, 813. [CrossRef]

45. Leach, J.K.; Van Tuyle, G.; Lin, P.-S.; Schmidt-Ullrich, R.; Mikkelsen, R.B. Ionizing radiation-induced, mitochondria-dependent generation of reactive oxygen/nitrogen. Cancer Res. 2001, 61, 3894-3901. [PubMed]

46. Winterbourn, C.C. Reconciling the chemistry and biology of reactive oxygen species. Nat. Chem. Biol. 2008, 4, 278. [CrossRef] [PubMed]

47. Zhu, X.; Raina, A.K.; Lee, H.G.; Casadesus, G.; Smith, M.A.; Perry, G. Oxidative stress signalling in Alzheimer's disease. Brain Res 2004, 1000, 32-39. [CrossRef]

48. Radi, E.; Formichi, P.; Battisti, C.; Federico, A. Apoptosis and oxidative stress in neurodegenerative diseases. J. Alzheimers Dis. 2014, 42 (Suppl. 3), S125-S152. [CrossRef]

49. Bhandary, B.; Marahatta, A.; Kim, H.R.; Chae, H.J. An involvement of oxidative stress in endoplasmic reticulum stress and its associated diseases. Int. J. Mol. Sci. 2012, 14, 434-456. [CrossRef]

50. Buettner, G.R. The pecking order of free radicals and antioxidants: Lipid peroxidation, $\alpha$-tocopherol, and ascorbate. Arch. Biochem. Biophys. 1993, 300, 535-543. [CrossRef]

51. Halliwell, B.; Gutteridge, J.M. Free Radicals in Biology and Medicine; Oxford University Press: Oxford, UK, 2015.

52. Valko, M.; Izakovic, M.; Mazur, M.; Rhodes, C.J.; Telser, J. Role of oxygen radicals in DNA damage and cancer incidence. Mol. Cell. Biochem. 2004, 266, 37-56. [CrossRef]

53. Wood, P.M. The potential diagram for oxygen at pH 7. Biochem. J. 1988, 253, 287-289. [CrossRef]

54. Gamblin, T.C.; King, M.E.; Kuret, J.; Berry, R.W.; Binder, L.I. Oxidative regulation of fatty acid-induced tau polymerization. Biochemistry 2000, 39, 14203-14210. [CrossRef]

55. Cente, M.; Filipcik, P.; Pevalova, M.; Novak, M. Expression of a truncated tau protein induces oxidative stress in a rodent model of tauopathy. Eur. J. Neurosci. 2006, 24, 1085-1090. [CrossRef]

56. Chen, L.; Na, R.; Gu, M.; Richardson, A.; Ran, Q. Lipid peroxidation up-regulates BACE1 expression in vivo: A possible early event of amyloidogenesis in Alzheimer's disease. J. Neurochem. 2008, 107, 197-207. [CrossRef]

57. Matsuoka, Y.; Picciano, M.; La Francois, J.; Duff, K. Fibrillar beta-amyloid evokes oxidative damage in a transgenic mouse model of Alzheimer's disease. Neuroscience 2001, 104, 609-613. [CrossRef]

58. Murakami, K.; Murata, N.; Noda, Y.; Tahara, S.; Kaneko, T.; Kinoshita, N.; Hatsuta, H.; Murayama, S.; Barnham, K.J.; Irie, K.; et al. SOD1 (copper/zinc superoxide dismutase) deficiency drives amyloid beta protein oligomerization and memory loss in mouse model of Alzheimer disease. J. Biol. Chem. 2011, 286, 44557-44568. [CrossRef]

59. Deibel, M.A.; Ehmann, W.D.; Markesbery, W.R. Copper, iron, and zinc imbalances in severely degenerated brain regions in Alzheimer's disease: Possible relation to oxidative stress. J. Neurol. Sci. 1996, 143, 137-142. [CrossRef]

60. Crapper, D.R.; Krishnan, S.S.; Dalton, A.J. Brain aluminum distribution in Alzheimer's disease and experimental neurofibrillary degeneration. Science 1973, 180, 511-513. [CrossRef]

61. Mandrekar-Colucci, S.; Landreth, G.E. Microglia and inflammation in Alzheimer's disease. CNS Neurol. Disord. Drug Targets 2010, 9, 156-167. [CrossRef]

62. Wang, X.; Wang, W.; Li, L.; Perry, G.; Lee, H.G.; Zhu, X. Oxidative stress and mitochondrial dysfunction in Alzheimer's disease. Biochim. Biophys. Acta 2014, 1842, 1240-1247. [CrossRef] [PubMed]

63. Choi, J.; Rees, H.D.; Weintraub, S.T.; Levey, A.I.; Chin, L.S.; Li, L. Oxidative modifications and aggregation of $\mathrm{Cu}, \mathrm{Zn}$-superoxide dismutase associated with Alzheimer and Parkinson diseases. J. Biol. Chem. 2005, 280, 11648-11655. [CrossRef]

64. Martinez, A.; Carmona, M.; Portero-Otin, M.; Naudi, A.; Pamplona, R.; Ferrer, I. Type-dependent oxidative damage in frontotemporal lobar degeneration: Cortical astrocytes are targets of oxidative damage. J. Neuropathol. Exp. Neurol. 2008, 67, 1122-1136. [CrossRef] [PubMed] 
65. De Leo, M.E.; Borrello, S.; Passantino, M.; Palazzotti, B.; Mordente, A.; Daniele, A.; Filippini, V.; Galeotti, T.; Masullo, C. Oxidative stress and overexpression of manganese superoxide dismutase in patients with Alzheimer's disease. Neurosci. Lett. 1998, 250, 173-176. [CrossRef]

66. Dias-Santagata, D.; Fulga, T.A.; Duttaroy, A.; Feany, M.B. Oxidative stress mediates tau-induced neurodegeneration in Drosophila. J. Clin. Investig. 2007, 117, 236-245. [CrossRef] [PubMed]

67. Jenner, P.; Olanow, C.W. Understanding cell death in Parkinson's disease. Ann. Neurol. 1998, 44, S72-S84. [CrossRef] [PubMed]

68. Rossi, L.; Squitti, R.; Pasqualetti, P.; Marchese, E.; Cassetta, E.; Forastiere, E.; Rotilio, G.; Rossini, P.M.; Finazzi-Agro, A. Red blood cell copper, zinc superoxide dismutase activity is higher in Alzheimer's disease and is decreased by D-penicillamine. Neurosci. Lett 2002, 329, 137-140. [CrossRef]

69. Perry, T.L.; Hansen, S.; Jones, K. Brain amino acids and glutathione in progressive supranuclear palsy. Neurology 1988, 38, 943-946. [CrossRef]

70. Fitzmaurice, P.S.; Ang, L.; Guttman, M.; Rajput, A.H.; Furukawa, Y.; Kish, S.J. Nigral glutathione deficiency is not specific for idiopathic Parkinson's disease. Mov. Disord. 2003, 18, 969-976. [CrossRef]

71. Wojsiat, J.; Zoltowska, K.M.; Laskowska-Kaszub, K.; Wojda, U. Oxidant/Antioxidant Imbalance in Alzheimer's Disease: Therapeutic and Diagnostic Prospects. Oxid. Med. Cell Longev. 2018, 2018, 6435861. [CrossRef]

72. Youssef, P.; Chami, B.; Lim, J.; Middleton, T.; Sutherland, G.T.; Witting, P.K. Evidence supporting oxidative stress in a moderately affected area of the brain in Alzheimer's disease. Sci. Rep. 2018, 8, 11553. [CrossRef] [PubMed]

73. Nikam, S.; Nikam, P.; Ahaley, S.K.; Sontakke, A.V. Oxidative stress in Parkinson's disease. Indian J. Clin. Biochem. 2009, 24, 98-101. [CrossRef] [PubMed]

74. Torres, L.L.; Quaglio, N.B.; de Souza, G.T.; Garcia, R.T.; Dati, L.M.; Moreira, W.L.; Loureiro, A.P.; de Souza-Talarico, J.N.; Smid, J.; Porto, C.S.; et al. Peripheral oxidative stress biomarkers in mild cognitive impairment and Alzheimer's disease. J. Alzheimers Dis. 2011, 26, 59-68. [CrossRef] [PubMed]

75. Aoyama, K.; Matsubara, K.; Kobayashi, S. Aging and oxidative stress in progressive supranuclear palsy. Eur. J. Neurol. 2006, 13, 89-92. [CrossRef]

76. Damier, P.; Hirsch, E.C.; Zhang, P.; Agid, Y.; Javoy-Agid, F. Glutathione peroxidase, glial cells and Parkinson's disease. Neuroscience 1993, 52, 1-6. [CrossRef]

77. Odetti, P.; Garibaldi, S.; Norese, R.; Angelini, G.; Marinelli, L.; Valentini, S.; Menini, S.; Traverso, N.; Zaccheo, D.; Siedlak, S.; et al. Lipoperoxidation is selectively involved in progressive supranuclear palsy. J. Neuropathol. Exp. Neurol. 2000, 59, 393-397. [CrossRef]

78. Gerst, J.L.; Siedlak, S.L.; Nunomura, A.; Castellani, R.; Perry, G.; Smith, M.A. Role of oxidative stress in frontotemporal dementia. Dement. Geriatr. Cogn. Disord. 1999, 10 (Suppl. 1), 85-87. [CrossRef]

79. Sudha, K.; Rao, A.V.; Rao, S.; Rao, A. Free radical toxicity and antioxidants in Parkinson's disease. Neurol. India 2003, 51, 60-62. [PubMed]

80. Albers, D.S.; Augood, S.J.; Martin, D.M.; Standaert, D.G.; Vonsattel, J.P.; Beal, M.F. Evidence for oxidative stress in the subthalamic nucleus in progressive supranuclear palsy. J. Neurochem. 1999, 73, 881-884. [CrossRef] [PubMed]

81. Zarkovic, K. 4-Hydroxynonenal and neurodegenerative diseases. Mol. Asp. Med. 2003, 24, $293-303$. [CrossRef]

82. Yoritaka, A.; Hattori, N.; Uchida, K.; Tanaka, M.; Stadtman, E.R.; Mizuno, Y. Immunohistochemical detection of 4-hydroxynonenal protein adducts in Parkinson disease. Proc. Natl. Acad. Sci. USA 1996, 93, 2696-2701. [CrossRef] [PubMed]

83. Ono, K.; Yamada, M. Vitamin A and Alzheimer's disease. Geriatr. Gerontol. Int. 2012, 12, 180-188. [CrossRef] [PubMed]

84. Kook, S.Y.; Lee, K.M.; Kim, Y.; Cha, M.Y.; Kang, S.; Baik, S.H.; Lee, H.; Park, R.; Mook-Jung, I. High-dose of vitamin $C$ supplementation reduces amyloid plaque burden and ameliorates pathological changes in the brain of 5XFAD mice. Cell Death Dis. 2014, 5, e1083. [CrossRef] [PubMed]

85. Lloret, A.; Esteve, D.; Monllor, P.; Cervera-Ferri, A.; Lloret, A. The Effectiveness of Vitamin E Treatment in Alzheimer's Disease. Int. J. Mol. Sci. 2019, 20, 879. [CrossRef]

86. Castellani, R.; Smith, M.A.; Richey, P.L.; Kalaria, R.; Gambetti, P.; Perry, G. Evidence for oxidative stress in Pick disease and corticobasal degeneration. Brain Res 1995, 696, 268-271. [CrossRef] 
87. Ihara, Y.; Chuda, M.; Kuroda, S.; Hayabara, T. Hydroxyl radical and superoxide dismutase in blood of patients with Parkinson's disease: Relationship to clinical data. J. Neurol. Sci. 1999, 170, 90-95. [CrossRef]

88. Forsyth, C.B.; Shannon, K.M.; Kordower, J.H.; Voigt, R.M.; Shaikh, M.; Jaglin, J.A.; Estes, J.D.; Dodiya, H.B.; Keshavarzian, A. Increased intestinal permeability correlates with sigmoid mucosa alpha-synuclein staining and endotoxin exposure markers in early Parkinson's disease. PLoS ONE 2011, 6, e28032. [CrossRef]

89. Kikuchi, A.; Takeda, A.; Onodera, H.; Kimpara, T.; Hisanaga, K.; Sato, N.; Nunomura, A.; Castellani, R.J.; Perry, G.; Smith, M.A.; et al. Systemic increase of oxidative nucleic acid damage in Parkinson's disease and multiple system atrophy. Neurobiol. Dis. 2002, 9, 244-248. [CrossRef] [PubMed]

90. Roostaei, T.; Felsky, D.; Nazeri, A.; de Jager, P.L.; Schneider, J.A.; Bennett, D.A.; Voineskos, A.N.; Alzheimer's Disease Neuroimaging Initiative. Genetic influence of plasma homocysteine on Alzheimer's disease. Neurobiol. Aging 2018, 62, 243.e7-243.e14. [CrossRef] [PubMed]

91. Wang, P.; Guan, P.P.; Wang, T.; Yu, X.; Guo, J.J.; Wang, Z.Y. Aggravation of Alzheimer's disease due to the COX-2-mediated reciprocal regulation of IL-1beta and Abeta between glial and neuron cells. Aging Cell 2014, 13, 605-615. [CrossRef]

92. Martin, E.; Rosenthal, R.E.; Fiskum, G. Pyruvate dehydrogenase complex: Metabolic link to ischemic brain injury and target of oxidative stress. J. Neurosci. Res. 2005, 79, 240-247. [CrossRef]

93. Shi, Q.; Xu, H.; Kleinman, W.A.; Gibson, G.E. Novel functions of the alpha-ketoglutarate dehydrogenase complex may mediate diverse oxidant-induced changes in mitochondrial enzymes associated with Alzheimer's disease. Biochim. Biophys. Acta 2008, 1782, 229-238. [CrossRef] [PubMed]

94. Zhang, Y.; Dai, M.; Yuan, Z. Methods for the detection of reactive oxygen species. Anal. Methods 2018, 10, 4625-4638. [CrossRef]

95. Chen, X.; Wang, F.; Hyun, J.Y.; Wei, T.; Qiang, J.; Ren, X.; Shin, I.; Yoon, J. Recent progress in the development of fluorescent, luminescent and colorimetric probes for detection of reactive oxygen and nitrogen species. Chem. Soc. Rev. 2016, 45, 2976-3016. [CrossRef]

96. Andina, D.; Leroux, J.C.; Luciani, P. Ratiometric fluorescent probes for the detection of reactive oxygen species. Chemistry 2017, 23, 13549-13573. [CrossRef] [PubMed]

97. Gomes, A.; Fernandes, E.; Lima, J.L. Fluorescence probes used for detection of reactive oxygen species. J. Biochem. Biophys. Methods 2005, 65, 45-80. [CrossRef] [PubMed]

98. Lo, L.-C.; Chu, C.-Y. Development of highly selective and sensitive probes for hydrogen peroxide. Chem. Commun. 2003, 7, 2728-2729. [CrossRef]

99. Chang, M.C.; Pralle, A.; Isacoff, E.Y.; Chang, C.J. A selective, cell-permeable optical probe for hydrogen peroxide in living cells. J. Am. Chem. Soc. 2004, 126, 15392-15393. [CrossRef] [PubMed]

100. Lippert, A.R.; van de Bittner, G.C.; Chang, C.J. Boronate oxidation as a bioorthogonal reaction approach for studying the chemistry of hydrogen peroxide in living systems. Acc. Chem. Res. 2011, 44, 793-804. [CrossRef]

101. Kuivila, H.G.; Armour, A.G. Electrophilic displacement reactions. IX. Effects of substituents on rates of reactions between hydrogen peroxide and benzeneboronic acid1-3. J. Am. Chem. Soc. 1957, 79, 5659-5662. [CrossRef]

102. Medvedeva, N.; Martin, V.V.; Weis, A.L.; Likhtenshten, G.I. Dual fluorophore-nitronyl probe for investigation of superoxide dynamics and antioxidant status of biological systems. J. Photochem. Photobiol. A Chem. 2004, 163, 45-51. [CrossRef]

103. Afanasev, I. On mechanism of superoxide signaling under physiological and pathophysiological conditions. Med. Hypotheses 2005, 64, 127-129. [CrossRef] [PubMed]

104. Xu, K.; Liu, X.; Tang, B. A phosphinate-based red fluorescent probe for imaging the superoxide radical anion generated by RAW264. 7 macrophages. ChemBioChem 2007, 8, 453-458. [CrossRef]

105. Hu, J.J.; Wong, N.-K.; Ye, S.; Chen, X.; Lu, M.-Y.; Zhao, A.Q.; Guo, Y.; Ma, A.C.-H.; Leung, A.Y.-H.; Shen, J. Fluorescent probe HKSOX-1 for imaging and detection of endogenous superoxide in live cells and in vivo. J. Am. Chem. Soc. 2015, 137, 6837-6843. [CrossRef] [PubMed]

106. Maeda, H.; Yamamoto, K.; Nomura, Y.; Kohno, I.; Hafsi, L.; Ueda, N.; Yoshida, S.; Fukuda, M.; Fukuyasu, Y.; Yamauchi, Y. A design of fluorescent probes for superoxide based on a nonredox mechanism. J. Am. Chem. Soc. 2005, 127, 68-69. [CrossRef]

107. Murale, D.P.; Kim, H.; Choi, W.S.; Churchill, D.G. Highly selective excited state intramolecular proton transfer (ESIPT)-based superoxide probing. Organ. Lett. 2013, 15, 3946-3949. [CrossRef] [PubMed] 
108. Hong, S.C.; Murale, D.P.; Jang, S.Y.; Haque, M.M.; Seo, M.; Lee, S.; Woo, D.H.; Kwon, J.; Song, C.S.; Kim, Y.K. Discrimination of Avian Influenza Virus Subtypes using Host-Cell Infection Fingerprinting by a Sulfinate-based Fluorescence Superoxide Probe. Angew. Chem. Int. Ed. 2018, 57, 9716-9721. [CrossRef]

109. You, Y.; Nam, W. Designing photoluminescent molecular probes for singlet oxygen, hydroxyl radical, and iron-oxygen species. Chem. Sci. 2014, 5, 4123-4135. [CrossRef]

110. Ohashi, T.; Mizutani, A.; Murakami, A.; Kojo, S.; Ishii, T.; Taketani, S. Rapid oxidation of dichlorodihydrofluorescin with heme and hemoproteins: Formation of the fluorescein is independent of the generation of reactive oxygen species. FEBS Lett. 2002, 511, 21-27. [CrossRef]

111. Kundu, K.; Knight, S.F.; Willett, N.; Lee, S.; Taylor, W.R.; Murthy, N. Hydrocyanines: A class of fluorescent sensors that can image reactive oxygen species in cell culture, tissue, and in vivo. Angew. Chem. Int. Ed. 2009, 48, 299-303. [CrossRef] [PubMed]

112. Yuan, L.; Lin, W.; Song, J. Ratiometric fluorescent detection of intracellular hydroxyl radicals based on a hybrid coumarin-cyanine platform. Chem. Commun. 2010, 46, 7930-7932. [CrossRef]

113. Aliaga, C.; Fuentealba, P.; Rezende, M.C.; Cárdenas, C. Mechanism of fluorophore quenching in a pre-fluorescent nitroxide probe: A theoretical illustration. Chem. Phys. Lett. 2014, 593, 89-92. [CrossRef]

114. Kang, P.; Foote, C.S. Formation of transient intermediates in low-temperature photosensitized oxidation of an 8-13C-guanosine derivative. J. Am. Chem. Soc. 2002, 124, 4865-4873. [CrossRef]

115. Umezawa, N.; Tanaka, K.; Urano, Y.; Kikuchi, K.; Higuchi, T.; Nagano, T. Novel fluorescent probes for singlet oxygen. Angew. Chem. Int. Ed. 1999, 38, 2899-2901. [CrossRef]

116. Wang, S.; Chen, L.; Jangili, P.; Sharma, A.; Li, W.; Hou, J.-T.; Qin, C.; Yoon, J.; Kim, J.S. Design and applications of fluorescent detectors for peroxynitrite. Coord. Chem. Rev. 2018, 374, 36-54. [CrossRef]

117. Wang, B.; Yu, F.; Li, P.; Sun, X.; Han, K. A BODIPY fluorescence probe modulated by selenoxide spirocyclization reaction for peroxynitrite detection and imaging in living cells. Dyes Pigment. 2013, 96, 383-390. [CrossRef]

118. Manjare, S.T.; Kim, Y.; Churchill, D.G. Selenium-and tellurium-containing fluorescent molecular probes for the detection of biologically important analytes. Acc. Chem. Res. 2014, 47, 2985-2998. [CrossRef]

119. Lou, Z.; Li, P.; Han, K. Redox-responsive fluorescent probes with different design strategies. Acc. Chem. Res. 2015, 48, 1358-1368. [CrossRef] [PubMed]

120. Iverson, N.; Hofferber, E.; Stapleton, J. Nitric Oxide Sensors for Biological Applications. Chemosensors 2018,6 , 8. [CrossRef]

121. Vegesna, G.K.; Sripathi, S.R.; Zhang, J.; Zhu, S.; He, W.; Luo, F.-T.; Jahng, W.J.; Frost, M.; Liu, H. Highly water-soluble BODIPY-based fluorescent probe for sensitive and selective detection of nitric oxide in living cells. ACS Appl. Mater. Interfaces 2013, 5, 4107-4112. [CrossRef]

122. Kim, J.; Kim, Y. A water-soluble sulfonate-BODIPY based fluorescent probe for selective detection of $\mathrm{HOCl} / \mathrm{OCl}-$ in aqueous media. Analyst 2014, 139, 2986-2989. [CrossRef] [PubMed]

123. Yang, J.; Zhang, X.; Yuan, P.; Yang, J.; Xu, Y.; Grutzendler, J.; Shao, Y.; Moore, A.; Ran, C. Oxalate-curcumin-based probe for micro- and macroimaging of reactive oxygen species in Alzheimer's disease. Proc. Natl. Acad. Sci. USA 2017, 114, 12384-12389. [CrossRef]

124. Yang, J.; Yang, J.; Liang, S.H.; Xu, Y.; Moore, A.; Ran, C. Imaging hydrogen peroxide in Alzheimer's disease via cascade signal amplification. Sci. Rep. 2016, 6, 35613. [CrossRef] [PubMed]

125. Yang, J.; Yang, J.; Li, Y.; Xu, Y.; Ran, C. Near-infrared Fluorescence Ocular Imaging (NIRFOI) of Alzheimer's Disease. Mol. Imaging Biol. 2019, 21, 35-43. [CrossRef] [PubMed]

126. Wang, H.; Mu, X.Y.; Yang, J.; Liang, Y.Y.; Zhang, X.D.; Ming, D. Brain imaging with near-infrared fluorophores. Coord. Chem. Rev. 2019, 380, 550-571. [CrossRef]

127. Needham, L.M.; Weber, J.; Fyfe, J.W.B.; Kabia, O.M.; Do, D.T.; Klimont, E.; Zhang, Y.; Rodrigues, M.; Dobson, C.M.; Ghandi, S.; et al. Bifunctional fluorescent probes for detection of amyloid aggregates and reactive oxygen species. $R$. Soc. Open Sci. 2018, 5, 171399. [CrossRef]

128. Xu, K.; Liu, X.; Tang, B.; Yang, G.; Yang, Y.; An, L. Design of a phosphinate-based fluorescent probe for superoxide detection in mouse peritoneal macrophages. Chemistry 2007, 13, 1411-1416. [CrossRef]

129. Yang, X.F.; Guo, X.Q. Investigation of the anthracene-nitroxide hybrid molecule as a probe for hydroxyl radicals. Analyst 2001, 126, 1800-1804. [CrossRef]

130. Leikert, J.F.; Rathel, T.R.; Muller, C.; Vollmar, A.M.; Dirsch, V.M. Reliable in vitro measurement of nitric oxide released from endothelial cells using low concentrations of the fluorescent probe 4,5-diaminofluorescein. FEBS Lett. 2001, 506, 131-134. [CrossRef] 
131. Park, S.Y.; Kim, H.S.; Cho, E.K.; Kwon, B.Y.; Phark, S.; Hwang, K.W.; Sul, D. Curcumin protected PC12 cells against beta-amyloid-induced toxicity through the inhibition of oxidative damage and tau hyperphosphorylation. Food Chem. Toxicol. 2008, 46, 2881-2887. [CrossRef]

132. Stack, C.; Jainuddin, S.; Elipenahli, C.; Gerges, M.; Starkova, N.; Starkov, A.A.; Jove, M.; Portero-Otin, M.; Launay, N.; Pujol, A.; et al. Methylene blue upregulates Nrf2/ARE genes and prevents tau-related neurotoxicity. Hum. Mol. Genet. 2014, 23, 3716-3732. [CrossRef]

133. Elipenahli, C.; Stack, C.; Jainuddin, S.; Gerges, M.; Yang, L.; Starkov, A.; Beal, M.F.; Dumont, M. Behavioral improvement after chronic administration of coenzyme Q10 in P301S transgenic mice. J. Alzheimers Dis. 2012, 28, 173-182. [CrossRef]

134. Morroni, F.; Tarozzi, A.; Sita, G.; Bolondi, C.; Zolezzi Moraga, J.M.; Cantelli-Forti, G.; Hrelia, P. Neuroprotective effect of sulforaphane in 6-hydroxydopamine-lesioned mouse model of Parkinson's disease. Neurotoxicology 2013, 36, 63-71. [CrossRef]

135. Takenouchi, T.; Sekiyama, K.; Sekigawa, A.; Fujita, M.; Waragai, M.; Sugama, S.; Iwamaru, Y.; Kitani, H.; Hashimoto, M. P2X7 receptor signaling pathway as a therapeutic target for neurodegenerative diseases. Arch. Immunol. Ther. Exp. (Warsz.) 2010, 58, 91-96. [CrossRef]

136. Clausen, A.; Xu, X.; Bi, X.; Baudry, M. Effects of the superoxide dismutase/catalase mimetic EUK-207 in a mouse model of Alzheimer's disease: Protection against and interruption of progression of amyloid and tau pathology and cognitive decline. J. Alzheimers Dis. 2012, 30, 183-208. [CrossRef]

137. Zhao, X.; Zhang, M.; Li, C.; Jiang, X.; Su, Y.; Zhang, Y. Benefits of Vitamins in the Treatment of Parkinson's Disease. Oxid. Med. Cell Longev. 2019, 2019, 9426867. [CrossRef]

138. Cente, M.; Filipcik, P.; Mandakova, S.; Zilka, N.; Krajciova, G.; Novak, M. Expression of a truncated human tau protein induces aqueous-phase free radicals in a rat model of tauopathy: Implications for targeted antioxidative therapy. J. Alzheimers Dis. 2009, 17, 913-920. [CrossRef]

139. Nakashima, H.; Ishihara, T.; Yokota, O.; Terada, S.; Trojanowski, J.Q.; Lee, V.M.; Kuroda, S. Effects of alpha-tocopherol on an animal model of tauopathies. Free Radic. Biol. Med. 2004, 37, 176-186. [CrossRef]

140. Taghizadeh, M.; Tamtaji, O.R.; Dadgostar, E.; Daneshvar Kakhaki, R.; Bahmani, F.; Abolhassani, J.; Aarabi, M.H.; Kouchaki, E.; Memarzadeh, M.R.; Asemi, Z. The effects of omega-3 fatty acids and vitamin E co-supplementation on clinical and metabolic status in patients with Parkinson's disease: A randomized, double-blind, placebo-controlled trial. Neurochem. Int. 2017, 108, 183-189. [CrossRef]

141. Grossi, C.; Francese, S.; Casini, A.; Rosi, M.C.; Luccarini, I.; Fiorentini, A.; Gabbiani, C.; Messori, L.; Moneti, G.; Casamenti, F. Clioquinol decreases amyloid-beta burden and reduces working memory impairment in a transgenic mouse model of Alzheimer's disease. J. Alzheimers Dis. 2009, 17, 423-440. [CrossRef]

142. Faux, N.G.; Ritchie, C.W.; Gunn, A.; Rembach, A.; Tsatsanis, A.; Bedo, J.; Harrison, J.; Lannfelt, L.; Blennow, K.; et al. PBT2 rapidly improves cognition in Alzheimer's Disease: Additional phase II analyses. J. Alzheimers Dis. 2010, 20, 509-516. [CrossRef] [PubMed]

143. Crouch, P.J.; Hung, L.W.; Adlard, P.A.; Cortes, M.; Lal, V.; Filiz, G.; Perez, K.A.; Nurjono, M.; Caragounis, A.; $\mathrm{Du}, \mathrm{T}$; ; et al. Increasing $\mathrm{Cu}$ bioavailability inhibits Abeta oligomers and tau phosphorylation. Proc. Natl. Acad. Sci. USA 2009, 106, 381-386. [CrossRef]

144. Crapper McLachlan, D.R.; Dalton, A.J.; Kruck, T.P.; Bell, M.Y.; Smith, W.L.; Kalow, W.; Andrews, D.F. Intramuscular desferrioxamine in patients with Alzheimer's disease. Lancet 1991, 337, 1304-1308. [CrossRef]

145. Lejri, I.; Grimm, A.; Miesch, M.; Geoffroy, P.; Eckert, A.; Mensah-Nyagan, A.G. Allopregnanolone and its analog BR 297 rescue neuronal cells from oxidative stress-induced death through bioenergetic improvement. Biochim. Biophys. Acta Mol. Basis Dis. 2017, 1863, 631-642. [CrossRef] [PubMed]

146. Perez-Gonzalez, R.; Pascual, C.; Antequera, D.; Bolos, M.; Redondo, M.; Perez, D.I.; Perez-Grijalba, V.; Krzyzanowska, A.; Sarasa, M.; Gil, C.; et al. Phosphodiesterase 7 inhibitor reduced cognitive impairment and pathological hallmarks in a mouse model of Alzheimer's disease. Neurobiol. Aging 2013, 34, 2133-2145. [CrossRef] [PubMed]

147. Turner, R.S.; Thomas, R.G.; Craft, S.; van Dyck, C.H.; Mintzer, J.; Reynolds, B.A.; Brewer, J.B.; Rissman, R.A.; Raman, R.; Aisen, P.S. A randomized, double-blind, placebo-controlled trial of resveratrol for Alzheimer disease. Neurology 2015, 85, 1383-1391. [CrossRef] 
148. Dysken, M.W.; Sano, M.; Asthana, S.; Vertrees, J.E.; Pallaki, M.; Llorente, M.; Love, S.; Schellenberg, G.D.; McCarten, J.R.; Malphurs, J.; et al. Effect of vitamin E and memantine on functional decline in Alzheimer disease: The TEAM-AD VA cooperative randomized trial. JAMA 2014, 311, 33-44. [CrossRef]

149. Ibrahim, N.F.; Yanagisawa, D.; Durani, L.W.; Hamezah, H.S.; Damanhuri, H.A.; Wan Ngah, W.Z.; Tsuji, M.; Kiuchi, Y.; Ono, K.; Tooyama, I. Tocotrienol-Rich Fraction Modulates Amyloid Pathology and Improves Cognitive Function in AbetaPP/PS1 Mice. J. Alzheimers Dis. 2017, 55, 597-612. [CrossRef]

(C) 2019 by the authors. Licensee MDPI, Basel, Switzerland. This article is an open access article distributed under the terms and conditions of the Creative Commons Attribution (CC BY) license (http://creativecommons.org/licenses/by/4.0/). 